University of Nebraska - Lincoln

DigitalCommons@University of Nebraska - Lincoln

1978

\title{
Genetic Method for the Preferential Elimination of Females of Anopheles albimanus
}

\author{
J. A. Seawright \\ P. E. Kaiser \\ D. A. Dame \\ C. S. Lofgren
}

Follow this and additional works at: https://digitalcommons.unl.edu/entomologyother

Part of the Entomology Commons

Seawright, J. A.; Kaiser, P. E.; Dame, D. A.; and Lofgren, C. S., "Genetic Method for the Preferential Elimination of Females of Anopheles albimanus" (1978). Entomology Papers from Other Sources. 49. https://digitalcommons.unl.edu/entomologyother/49

This Article is brought to you for free and open access by the Entomology Collections, Miscellaneous at DigitalCommons@University of Nebraska - Lincoln. It has been accepted for inclusion in Entomology Papers from Other Sources by an authorized administrator of DigitalCommons@University of Nebraska - Lincoln. 


\section{Genetic Method for the Preferential Elimination of Females of Anopheles albimanus}

Abstract. Recent field experiments demonstrated the possibility of using the sterile male method for the control of Anopheles albimanus Wiedemann, the most important vector of human malaria in Central America. Until now there was no practical method for excluding females from the releases of sterile males. A genetic method was developed for the preferential elimination of females during any of the four life stages. This genetic sexing system utilizes propoxur (o-isopropoxyphenyl methylcarbamate) susceptibility as a recessive conditional lethal, a $T(Y: 2 R)$ translocation, and an $\operatorname{In}(2 R)$ inversion. The propoxur resistance allele (dominant) was linked to the $Y$ chromosome via a radiation-induced translocation, and genetic recombination was suppressed by inversions. In one of the strains produced, 99.7 percent of the females are eliminated when treated with propoxur, without male loss.

During an experiment conducted in $\mathrm{El}$ Salvador, Lofgren et al. (l) demonstrated the possibility of using the sterile male method for the control of Anopheles albimanus, an important vector of human malaria in Central America. In view of the widespread occurrence of insecticide resistance in this species, the development of this alternate control method is most desirable and appropriate at this time. The success of the sterile male method relies on the efficient distribution of inundative releases of competitive, sterile males into the natural habitat of the target species. Therefore, a sound system must be available for the mass production of sterile males, but since the females of anopheline species are potential malaria vectors, they should be excluded from the releases. Also, if the females could be eliminated during the egg or early larval stages, the mass production of males could be conducted less expensively.
Since currently available methods for elimination of $A$. albimanus females in a mass production process are only 85 to 95 percent effective (unpublished data), we undertook the development of a genetic method for the preferential killing of females. We now describe the synthesis of a female-killing system for use in a mass production facility.

The genetic sexing scheme utilizes propoxur (o-isopropoxyphenyl methylcarbamate) susceptibility $\left(\mathrm{pr}^{s}\right)$ as a recessive conditional lethal, a $\mathrm{T}(\mathrm{Y}: 2 \mathrm{R})$ translocation, and an $\operatorname{In}(2 R)$ inversion. The locus for propoxur resistance $\left(p r^{r}\right)$, a dominant trait, is on the right arm of chromosome 2, and this allele was linked to the $\mathrm{Y}$ chromosome via a radiation-induced translocation. Adult homozygous resistant males $\left(p r^{r} / p r^{r}\right)$, less than 24 hours old, were irradiated with $1700 \mathrm{R}$ (dose rate $212 \mathrm{R} / \mathrm{min}$ ) from an $\mathrm{x}$-ray machine operated at $90 \mathrm{kV}$ (peak). These irradiated males were crossed to suscep- 
Table 1. Results of rearing $T(Y: 2 R)$ translocation strains treated as larvae with 20 parts of propoxur per million (data collected over five generations).

\begin{tabular}{ccccc}
\hline Strain & $\begin{array}{c}\text { Sterility } \\
(\%)\end{array}$ & $\begin{array}{c}\text { Number } \\
\text { of } \\
\text { males }\end{array}$ & $\begin{array}{c}\text { Number } \\
\text { of } \\
\text { females }\end{array}$ & $\begin{array}{c}\text { Percent } \\
\text { crossing } \\
\text { over }\end{array}$ \\
\hline T(Y:2R)2 & 34 & 425 & 127 & 23 \\
$T(Y: 2 R) 3$ & 52 & 759 & 276 & 27 \\
T(Y:2R)4 & 48 & 1471 & 130 & 8 \\
$T(Y: 2 R) 5$ & 49 & 793 & 176 & 6 \\
$T(Y: 2 R) 6$ & 52 & 762 & 190 & 19 \\
$T(Y: 2 R) 7$ & 57 & & 142 & 16 \\
\hline
\end{tabular}

Table 2. Results of rearing $T(Y: 2 R)$ translocation- $\operatorname{In}(2 \mathrm{R})$ inversion strains treated with propoxur.

\begin{tabular}{lcccc}
\hline \multicolumn{1}{c}{ Strain } & $\begin{array}{c}\text { Sterility } \\
(\%)\end{array}$ & $\begin{array}{c}\text { Number } \\
\text { of } \\
\text { males }\end{array}$ & $\begin{array}{c}\text { Number } \\
\text { of } \\
\text { females }\end{array}$ & $\begin{array}{c}\text { Percent } \\
\text { crossing } \\
\text { over }\end{array}$ \\
\hline $\operatorname{In}(2 \mathrm{R})[\mathrm{T}(\mathrm{Y}: 2 \mathrm{R}) 3] 1$ & 56 & 2372 & 55 & 2.3 \\
$\operatorname{In}(2 \mathrm{R})[\mathrm{T}(\mathrm{Y}: 2 \mathrm{R}) 3] 2$ & 46 & 2945 & 6 & 0.20 \\
$\operatorname{In}(2 \mathrm{R})[\mathrm{T}(\mathrm{Y}: 2 \mathrm{R}) 6] 1$ & 49 & 1975 & 41 & 2.0 \\
$\operatorname{In}(2 \mathrm{R})[\mathrm{T}(\mathrm{Y}: 2 \mathrm{R}) 4: \mathrm{T}(2 \mathrm{R}: 3 \mathrm{R})] 1$ & 65 & 807 & 17 & 2.1 \\
\hline
\end{tabular}

tible females $\left(p r^{s} / p r^{s}\right)$, and the resultant $F_{1}$ males were backcrossed to susceptible females. The backcross progeny from families that showed less than 60 percent egg hatch were single-family cultured (2) and treated in the larval stage with an exposure ( 30 minutes in 20 parts of propoxur per million) that killed the homozygotes $\left(p r^{s} / p^{s}\right)$, but not the heterozygotes $\left(\mathrm{pr}^{s} / \mathrm{pr}^{r}\right)$. Discriminating treatments are available for separating the two genotypes during the egg, larval, pupal, or adult stages (unpublished data). If an appropriate translocation were present in an $F_{1}$ male, then a distortion in sex ratio would be evident among his progeny. Chromosomal aberrations detected in this manner were confirmed by examination of salivary gland chromosomes with an established technique (3). A total of 1200 sperm were tested, and six $\mathrm{T}(\mathrm{Y}: 2 \mathrm{R})$ translocations were isolated (Table 1).

Since genetic recombination occurs in both sexes of $A$. albimanus, some heterozygous resistant females $\left(\mathrm{pr}^{r} / \mathrm{pr}^{s}\right)$ are produced each generation. For the stocks we studied, the recombination frequencies ranged from 0.06 to 0.27 . The male-linked translocations proved to be holandric, a fact strongly suggesting that the crossing over is restricted to the autosome.

To suppress the incidence of recombination, we irradiated males of these translocation stocks to induce an inversion. Several inversions were isolated, and the strains showing the least number of recombinant, resistant females are shown in Table 2. For clarification, the strain designation $\operatorname{In}(2 \mathrm{R})$ $[T(Y: 2 R) 3] 2$ identifies the second inversion induced from the $\mathrm{T}(\mathrm{Y}: 2 \mathrm{R}) 3$ translocation strain. The inversion covers part of the $\mathrm{Y}-2 \mathrm{R}$ chromosome that resulted from the original irradiation and includes the centromere of the $\mathrm{Y}$ chromosome. $\operatorname{In}(2 \mathrm{R})[\mathrm{T}(\mathrm{Y}: 2 \mathrm{R}) 3] 2$ is the most appropriate for the purpose of a mass production system because it has the maximum level of fertility (54 percent) and the minimum recombination frequency $(0.0016)$. It is of interest to note that the original $\mathrm{T}(\mathrm{Y}: 2 \mathrm{R}) 3$ strain usually produces 27 percent recombinant females.

$\operatorname{In}(2 \mathrm{R})[\mathrm{T}(\mathrm{Y}: 2 \mathrm{R}) 3] 2$ has been mass cultured for several generations and has proved to be quite suitable for that type
Of the four strains shown in Table 2 , of production. Exposure of this strain to propoxur eliminates 99.7 percent of the females. This elimination can be done in the egg stage or in subsequent stages of the life cycle, depending upon the need. Furthermore, since three pairs of chromosomes are found in this species it is a relatively simple matter to incorporate wild genome into the strain.

The genetic sexing system described herein is similar to those developed for Lucilia cuprina (4) and Anopheles gambiae (5). A "male-producing" strain was also developed in Musca domestica (6) by using a temperature-sensitive lethal and a male-determining autosome.

For those species of insect pests that can be controlled by the release of sterile males, the use of a genetic sexing system can be of great benefit, especially in the curtailment of rearing costs. However, cost is not the only consideration. The sterile male method has been considered unsuitable for some species where sexual separation is difficult because the females cause extensive damage or are potential disease vectors. In some cases, the treatment used to sterilize males is ineffective on the females. The development and implementation of genetic sexing systems could possibly increase the number of species for which the sterile male method can be used.

\section{J. A. Seawright}

P. E. KaISER

D. A. DAME, C. S. LofGren

Insects Affecting Man and Animals

Research Laboratory, U.S. Department

of Agriculture, P.O. Box 14565 ,

Gainesville, Florida 32604

\section{References and Note}

1. C. S. Lofgren, D. A. Dame, S. G. Breeland, D. E. Weidhaas, G. Jeffery, R. Kaiser, H. R. Ford, M. D. Boston, K. F. Baldwin, Am. J. Trop Med. Hyg. 23, 288 (1974)

2. M. G. Rabbani, J. A. Seawright, L. B. Leatherwood, Mosq. News 36, 100 (1976).

3. M. G. Rabbani and J. B. Kitzmiller, Am. J Trop. Med. Hyg. 24, 1019 (1975).

4. G. G. Foster, personal communication

5. C. F. Curtis, J. Akiyama, G. Davidson, Mosq News 36, 492 (1976)

6. I. C. McDonald, Science 172, 489 (1971)

7. We are indebted to C. F. Curtis and G. Davidson for kindly supplying the propoxur-resistant strain of $A$. albimanus. The research reported strain of $A$. albimanus. The research reported here was conducted in part with contract funds transferred from the Medical Research and DeGeneral, U.S. Army.

27 January 1978; revised 15 March 1978 